\title{
Impact of bus electrification on carbon emissions: The case of Stockholm
}

Citation for published version (APA):

Xylia, M., Leduc, S., Laurent, A-B., Patrizio, P., Van Der Meer, Y., Kraxner, F., \& Silveira, S. (2019).

Impact of bus electrification on carbon emissions: The case of Stockholm. Journal of Cleaner Production, 209, 74-87. https://doi.org/10.1016/j.jclepro.2018.10.085

Document status and date:

Published: 01/02/2019

DOI:

10.1016/j.jclepro.2018.10.085

Document Version:

Publisher's PDF, also known as Version of record

Document license:

Taverne

Please check the document version of this publication:

- A submitted manuscript is the version of the article upon submission and before peer-review. There can be important differences between the submitted version and the official published version of record.

People interested in the research are advised to contact the author for the final version of the publication, or visit the DOI to the publisher's website.

- The final author version and the galley proof are versions of the publication after peer review.

- The final published version features the final layout of the paper including the volume, issue and page numbers.

Link to publication

\footnotetext{
General rights rights.

- You may freely distribute the URL identifying the publication in the public portal. please follow below link for the End User Agreement:

www.umlib.nl/taverne-license

Take down policy

If you believe that this document breaches copyright please contact us at:

repository@maastrichtuniversity.nl

providing details and we will investigate your claim.
}

Copyright and moral rights for the publications made accessible in the public portal are retained by the authors and/or other copyright owners and it is a condition of accessing publications that users recognise and abide by the legal requirements associated with these

- Users may download and print one copy of any publication from the public portal for the purpose of private study or research.

- You may not further distribute the material or use it for any profit-making activity or commercial gain

If the publication is distributed under the terms of Article $25 \mathrm{fa}$ of the Dutch Copyright Act, indicated by the "Taverne" license above, 


\title{
Impact of bus electrification on carbon emissions: The case of Stockholm
}

\author{
Maria Xylia a, b, *, Sylvain Leduc c, Achille-B. Laurent ${ }^{\text {d }}$, Piera Patrizio c, \\ Yvonne van der Meer ${ }^{d}$, Florian Kraxner ${ }^{c}$, Semida Silveira ${ }^{a}$ \\ a Energy and Climate Studies Unit, KTH Royal Institute of Technology, Stockholm, Sweden \\ ${ }^{\mathrm{b}}$ Integrated Transport Research Lab (ITRL), KTH Royal Institute of Technology, Stockholm, Sweden \\ ${ }^{\mathrm{c}}$ International Institute for Applied Systems Analysis (IIASA), Laxenburg, Austria \\ ${ }^{\mathrm{d}}$ Biobased Materials Department, Maastricht University, Geleen, the Netherlands
}

\section{A R T I C L E I N F O}

\section{Article history:}

Received 29 January 2018

Received in revised form

25 September 2018

Accepted 9 October 2018

Available online 12 October 2018

\begin{abstract}
A B S T R A C T
This paper focuses on the potential impact of various options for decarbonization of public bus transport in Stockholm, with particular attention to electrification. An optimization model is used to locate electric bus chargers and to estimate the associated carbon emissions, using a life cycle perspective and various implementation scenarios. Emissions associated with fuels and batteries of electric powertrains are considered to be the two main factors affecting carbon emissions. The results show that, although higher battery capacities could help electrify more routes of the city's bus network, this does not necessarily lead to a reduction of the total emissions. The results show the lowest life cycle emissions occurring when electric buses use batteries with a capacity of $120 \mathrm{kWh}$. The fuel choices significantly influence the environmental impact of a bus network. For example, the use of electricity is a better choice than first generation biofuels from a carbon emission perspective. However, the use of second-generation biofuels, such as Hydrotreated Vegetable Oil (HVO), can directly compete with the Nordic electricity mix. Among all fuel options, certified renewable electricity has the lowest impact. The analysis also shows that electrification could be beneficial for reduction of local pollutants in the Stockholm inner city; however, the local emissions of public transport are much lower than emissions from private transport.
\end{abstract}

(c) 2018 Elsevier Ltd. All rights reserved.

\section{Introduction}

The Conference of the Parties to the UNFCCC (COP 21) held in December 2015 in Paris resulted in a historical agreement among 195 countries to reduce greenhouse gas (GHG) emissions and limit global temperature increase to $2^{\circ} \mathrm{C}$ (see e.g., European Commission, 2016). Cities will play an important role in this context. In fact, urban regions accounted for $64 \%$ of global primary energy use and 70\% of carbon emissions in 2013 (IEA, 2016).

One of the major challenges to achieve environmental sustainability in cities is the decarbonization of transport. The transport sector emissions represented $23 \%$ of the global emissions in 2013 , with road transport emissions accounting for $75 \%$ of the total emissions in the sector (IEA, 2015). By 2013, emissions from road

\footnotetext{
* Corresponding author. Energy and Climate Studies Unit, KTH Royal Institute of Technology, Stockholm, Sweden.
}

E-mail address: maria.xylia@energy.kth.se (M. Xylia). transport had increased by 68\% compared to 1990 (IEA, 2015). Electrification of road transport in combination with a modal shift towards public transport can be key to achieving decarbonization and energy efficiency improvement of the sector (Creutzig et al., 2015). In line with the above, Sweden has been testing solutions for bus transport electrification in various locations around the country. Electricity is one of the most attractive fuel options for Swedish public bus fleets, according to a survey among environmental managers of the Public Transport Authorities (PTAs) (Xylia and Silveira, 2017). A target of $80 \%$ electric city buses by 2030 and $100 \%$ by 2050 is suggested by the Swedish government (Regeringskansliet, 2013).

To make sure these solutions lead to lower carbon emissions, the climate change impact needs to be quantified. Different compositions of the electricity mix lead to different levels of carbon emissions, which needs to be accounted for. Furthermore, it is important to assess the impact of the components that are necessary for electrification, such as the batteries, over their whole life cycle. In order to quantify such impacts and compare them with 
other existing fuel alternatives, this study uses Life Cycle Assessment (LCA) (ISO, 2006) to quantify life cycle climate change impacts. LCA has the advantage of assessing the whole life cycle of a product, thereby avoiding shifting an impact from one stage to another in the life cycle (Jolliet et al., 2015).

The representation of life cycle carbon emissions in this paper is an enhancement of the model for electric bus network optimization originally presented in Xylia et al. (2017a). The model was applied to the city of Stockholm, Sweden. The main questions we aim to answer in this paper are the following: (i) How does large-scale electrification affect the life cycle carbon emissions of the Stockholm bus network and how does it compare to the use of other fuels? (ii) How do battery characteristics (e.g., capacity, specific energy) affect the environmental impact of electric buses? and (iii) What is the impact of bus electrification in terms of reduction of air pollutants in Stockholm's inner city? The overarching objective of the study is to quantify the climate change impact of bus transportation using different fuels, further elaborating on aspects such as battery impact on emissions as well as the impact of bus electrification on local air quality.

We measure the impact of emissions in carbon dioxide equivalents $\left(\mathrm{CO}_{2 \mathrm{eq}}\right)$, which translates all emissions into carbon equivalents and derive the global warming potential (GWP) for a given mixture of greenhouse gases. Other life cycle impact categories, such as eutrophication, human toxicity and acidification potentials are not included in this study. In addition to the reduction of greenhouse gas emissions, electrification of urban transportation can help to reduce pollutant emissions in the inner city, such as particulate matter (PM) and Nitrogen Oxides (NOx). Therefore, the study includes a local assessment of the potential local reduction of the above mentioned pollutants as a result of bus electrification. The emissions factors used are based on Stockholm specific data, and we compare available bus technologies during the use phase in bus transport.

Following the present introduction, Section 2 presents the literature review on this research topic, and highlights the contribution of this study. Section 3 presents the data and methods applied in the study. Section 4 presents the results, answering the three key questions related to the carbon emissions of a partially electrified bus network, the implications of different battery sizes, and the impacts of electrification on Stockholm's inner city in particular. Finally, conclusions on the study and future research directions are given in Section 5.

\section{Literature review}

Life cycle carbon emissions associated with public bus operation have been previously investigated in several studies. Chan et al. (2013) use the LCA methodology to assess greenhouse gas emissions along a busy transit corridor in Montreal, Canada. Different powertrain technologies (compressed natural gas, biodiesel and diesel electric hybrid) are compared using the GHGenius life cycle tool (Natural Resources Canada) and Motor Vehicle Emission Simulator (by USEPA) to simulate various speed scenarios. The authors conclude that emissions related to fuel consumption of the bus account for the largest share of life cycle emissions.

Lajunen and Lipman (2016) evaluate life cycle costs, energy consumption, and emissions of diesel, natural gas, hybrid electric, fuel cell hybrid and battery electric city buses. Hybrid buses have both an internal combustion engine and an electric engine or fuel cells. The results indicate significant emissions reduction for hybrid and electric buses compared to conventional fossil fueled buses. Energy consumption is calculated using the Autonomie vehicle simulation model for various types of operating cycles. Emissions associated with bus operation and fuel production in Finland and
California are considered.

Dreier et al. (2018) estimated Well-to-Wheel (WTW) fossil energy use and greenhouse gas (GHG) emissions for six types of city buses in the city of Curitiba, Brazil, including conventional, hybridelectric and plug-in hybrid-electric powertrains. The operation phase (Tank-to- Wheel, TTW) of the city buses was simulated using the Advanced Vehicle Simulator (ADVISOR) software. The study showed hybrid-electric and plug-in hybrid-electric two-axle city buses consuming 30\% and 75\% less WTW fossil energy per distance compared to a conventional two-axle city bus. This leads to a $27 \%$ reduction of WTW GHG emissions when a plug-in hybrid vehicle is used compared to a conventional city bus $\left(1115 \mathrm{gCO}_{2 \mathrm{eq}} / \mathrm{km}\right.$ compared to $1539 \mathrm{~g} \mathrm{CO}_{2 \mathrm{eq}} / \mathrm{km}$ for the conventional bus).

Mahmoud et al. (2016) present a holistic review of alternative powertrain technologies including economic, environmental, operational, and energy efficiency aspects. Hybrid electric, fuel cell and battery electric buses are compared to diesel buses. The authors conclude that, although the performance of electric buses is sensitive to energy profiles and operational demands, the battery electric buses that use electricity from renewable sources are the best option when considering environmental benefits and operational advantages. The authors also highlight the correlation of emission reduction potential from electric buses to the electricity mix used, i.e., emission reduction differs depending on the national electricity mixes considered, an issue that is also analyzed in the present study.

García Sánchez et al. (2013) highlight the impact of the electricity mix on life cycle emissions from electric buses, exploring the case of Spain. The study presents a global LCA for a fuel cell hybrid bus, a hybrid diesel electric bus, a battery electric bus and an internal combustion bus. The analysis shows an estimated 1670 $\mathrm{gCO}_{2 \mathrm{eq}} / \mathrm{km}$ for the diesel bus in the year 2010 , which is two times higher than the LCA value estimated for the battery electric bus $\left(790 \mathrm{gCO}_{2 \mathrm{eq}} / \mathrm{km}\right)$. Future shifts towards renewables in the Spanish electricity mix will lead to reduced emissions associated with battery electric buses.

Another study highlighting the impact of the electricity mix on the environmental effects of electric buses was done for Macau, China (Song et al., 2017). The authors conclude that, under current conditions and considering charging and distribution losses, electric bus emissions would exceed emissions of conventional diesel buses. Another case study for Macau quantifies the impact of electric bus use in terms of the amount of local pollutants. More specifically, battery electric buses can reduce WTW emissions of $\mathrm{NO}_{\mathrm{x}}$ and Volatile Organic Compounds (VOC) by $60-80 \%$, compared to a EURO IV diesel bus (He et al., 2018).

Other studies, such as Durango-Cohen and McKenzie (2017) and McKenzie and Durango-Cohen (2012), present LCA results for various powertrain technologies. However, battery electric buses are not part of their analyses, and only hybrid electric buses are considered. Abdul-Manan (2015) discusses the uncertainty of LCAs for electric vehicle emissions. Although not directly analyzing buses, the results offer valuable insights for the comparison between battery electric vehicles and internal combustion engine vehicles. The difference in greenhouse gas emission reduction between the two powertrain technologies is $43 \%$ in average, with a 95\% confidence interval.

The uncertainty of estimations of emissions indicated in various studies should always be kept in mind. The uncertainties surrounding emission assessments do not only originate from the LCA methodology per se. Uncertainties are also linked to the chosen methodological approach within the LCA including, for example, details of the electricity mix, marginal emissions or EU-ETS (EU Emissions Trading System) argumentation among others (see 
Ensslen et al., 2017; Jochem et al., 2015).

From the studies discussed above, we gather that different assumptions, differences in powertrain characteristics and driving cycles, as well as diverse fuel mixes used around the world influence the greenhouse gas emissions in each system. In other words, the actual emissions can vary significantly from one city to another entailing specific analysis before policies and actions are defined.

This study contributes to this field of knowledge by analyzing the emissions from various fuels and electricity mixes with an optimization model aimed at determining the location of bus charging infrastructure. In this way, one can observe impacts of electrification at larger-scale, i.e. for large bus networks. Emissions can be estimated for specific scenarios of infrastructure deployment, thus serving to guide the deployment of electric vehicles, for example, along with the transformation of energy mixes. In addition, optimal configurations for fuel choices, battery capacities and charging locations for electric public transport, and their costrelated implications can be determined.

\section{Methodology}

This section presents the methodology used to obtain the minimization of the carbon emissions of bus transport applied to the city of Stockholm. It is composed of two parts: the life cycle assessment to quantify greenhouse gas emissions, and the optimization model. As mentioned earlier, this optimization model is a new, expanded version of the model used in Xylia et al. (2017a). Here, the model component estimating emissions is enhanced with more detailed calculations for fuel-associated emissions and vehicle battery-associated emissions of the bus network selected. The objective of the study is to quantify the climate change impact of bus transportation using different fuels, as well as the battery impact in case electric buses are used.

\subsection{Life cycle assessment to calculate carbon emissions}

A comparative life cycle assessment (LCA) in line with the ISO 14044 standard (ISO, 2006) is used. The lifecycle impact of the powertrain and its maintenance, the road construction and the actual transportation service delivery have been excluded from the analysis, as they are considered to have similar impact regardless of the engine technology and fuel used. Additionally, according to previous literature, their impact on the total life cycle emissions is relatively low when compared to the impact of fuels or batteries. For example, diesel and electric hybrid powertrains have the same total vehicle cycle emissions, which is $8.5 \%$ of the total upstream emissions according to Chan et al. (2013), while the share of emissions from the chargers has been found to be even lower, that is, at around 1\% according to Bi et al. (2015). However, the specific design and sizing of each charger could potentially affect these values.

In this study, the carbon emissions of the various fuels and of the batteries were analyzed separately as described in the following sections.

\subsubsection{Fuel emissions}

The common functional unit used for the different fuels analyzed is one $\mathrm{kWh}$. The four alternatives included in this study, i.e. Hydrotreated Vegetable Oil (HVO), Fatty Acid Methyl Ester (FAME), certified renewable electricity and the Nordic electricity mix were modeled in Simapro V8.4 (Pré, 2016). SimaPro is a widely used LCA software for modeling and analyzing life cycles in a systematic way. The software analyses environmental impact of products and services across all the stages of their life cycle, such as manufacturing, distribution, use, and disposal. The ecoinvent v3.2 database (ecoinvent Centre, St Gallen, Switzerland) was used for background data. Ecoinvent is a Life Cycle Inventory (LCI) database which includes data on the life cycle environmental impact of various products and process in the areas of energy supply, agriculture, transport, biofuels, chemicals etc.

The carbon emissions were calculated with the IPCC 2013 GWP 100-year method (IPCC, 2007). The primary data for the biofuels were based on information published by the Swedish Energy Agency (2016), while data for the annual average electricity mix were extracted from information published by the IEA and Nordic Energy Research (2016). The estimation of life cycle emissions for biofuels is reported by the Swedish Energy Agency according to the Annex V of the EU Renewable Energy Directive (RED) (European Parliament, 2009) (see Table 1). The emissions reported are Wellto-Wheel (WTW), which means that the whole life cycle of the fuel is covered, from feedstock recovery to finished fuel and the combustion of the fuel in the engine. We compare the emissions factors reported by the Swedish Energy Agency with the LCA model results as shown in Table 1 . The comparison shows small differences between our estimations and the literature for the case of HVO and the Nordic electricity mix, while somehow larger differences occur for the case of FAME and certified renewable electricity. For the case of FAME, the LCA model estimates lower emission factors $(-17 \%)$ than the literature, while for certified electricity the model values are $32 \%$ higher than the available data for a Swedish case of electricity from renewable sources.

HVO is modeled in Simapro, based on ecoinvent data for an estimated mix of rapeseed oil (11\%), vegetable and animal oil residues (32\%), slaughterhouse residues (29\%), palm oil (14\%) and crude tall oil (14\%), with information from the statistics for 2015 (Swedish Energy Agency, 2016). The raw tall oil is mainly produced in Sweden, with a small amount coming from Finland and the USA (5\% and 3\%, respectively) (Swedish Energy Agency, 2016). The slaughterhouse residues originate generally from other EU countries, and the same is true for vegetable and animal oil residues. The rapeseed oil originates mainly from EU countries, with a smaller share originating from Australia and Russia (10\% and 7\%, respectively) (Swedish Energy Agency, 2016). HVO imports by country are illustrated in Fig. 1. Defining the origin of the fuels in use is crucial for the accuracy of the emissions analysis in the LCA.

FAME has been in the market longer time than HVO. Both FAME and HVO are renewable fuels that can substitute fossil diesel. In Sweden, all FAME is produced from rapeseed oil (RME). One of the reasons why RME is commonly used is that it gives the biodiesel attributes that can withstand the cold Nordic climate (Swedish

Table 1

Emission factors for the fuels considered in the analysis (2015 values).

\begin{tabular}{llll}
\hline Fuel & $\begin{array}{l}\text { Emission factor } \\
\text { literature }(\mathrm{g} \\
\left.\mathrm{CO}_{2 \mathrm{eq}} / \mathrm{kWh}\right)\end{array}$ & $\begin{array}{l}\text { Emission factor } \\
\text { calculated in LCA model } \\
\left(\mathrm{g} \mathrm{CO}_{2 \mathrm{eq}} / \mathrm{kWh}\right)\end{array}$ & $\begin{array}{l}\text { Comparison } \\
\text { literature vs. LCA } \\
\text { model (in \%) }\end{array}$ \\
\hline $\begin{array}{l}\text { Hydrotreated } \\
\text { Vegetable } \\
\quad \text { Oil (HVO) }\end{array}$ & $43^{\mathrm{a}}$ & 39.6 & $-8 \%$ \\
$\begin{array}{l}\text { Fatty Acid } \\
\text { Methyl Ester } \\
\quad 140^{\mathrm{a}}\end{array}$ & 116 & $-17 \%$ \\
$\begin{array}{l}\text { Certified } \\
\text { renewable } \\
\text { electricity }\end{array}$ & $9^{\mathrm{b}}$ & 11.9 & $32 \%$ \\
$\begin{array}{l}\text { Nordic } \\
\text { electricity } \\
\text { mix }\end{array}$ & 124 a & 136 & $10 \%$ \\
\hline $\begin{array}{l}\text { a Swedish Energy Agency (2016) } \\
\text { b Vattenfall (2017). }\end{array}$ &
\end{tabular}




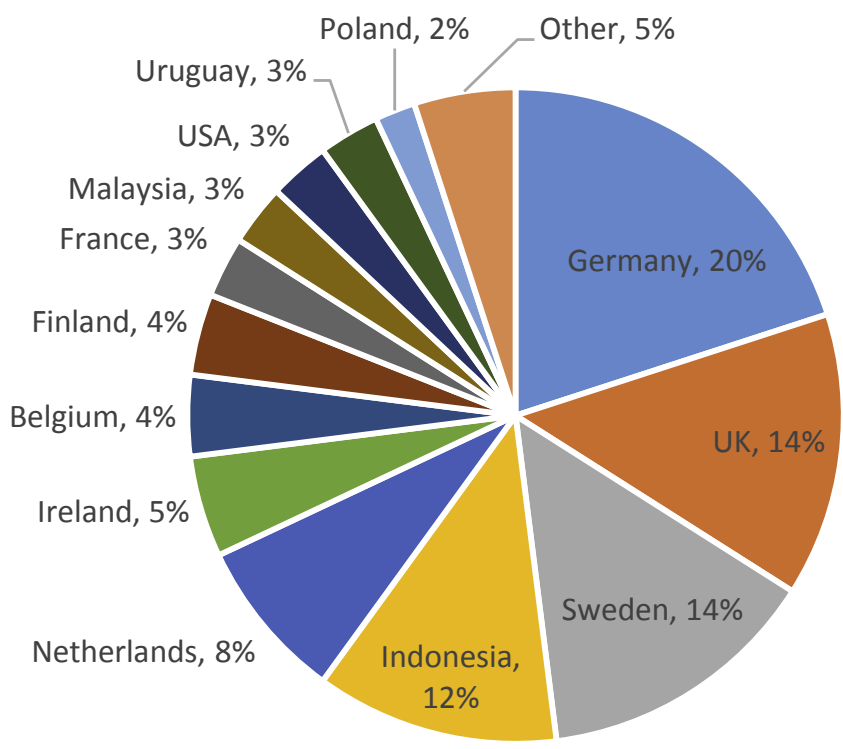

Fig. 1. Origin of HVO imports to Sweden (data extracted from Swedish Energy Agency, 2016) (Note: Other includes Austria, Lithuania, Australia, Denmark, Spain, Romania, Italy, Slovakia, Russia, Latvia and Belarus (in order of importance)).

Energy Agency, 2016). FAME imports by country are illustrated in Fig. 2.

Electricity, unless certified as renewable electricity, is assumed to have the characteristics of the Nordic mix based on data for the electricity generation per Nordic country for the year 2013 (see Fig. 3). The share of each primary energy source in the mix is illustrated in Fig. 4. Certified electricity is modeled as "BraMiljöval" electricity ("green electricity"), i.e. assumed to originate from hydropower (95\%) and wind (5\%) (Vattenfall, 2017). It should be noted that, as both the electricity mix composition and origin of the fuel changes over time, there can be differences in the emission factors from year to year.

The biggest impact on the emissions of the Nordic electricity mix is coming from the use of coal in Denmark and Finland. Both

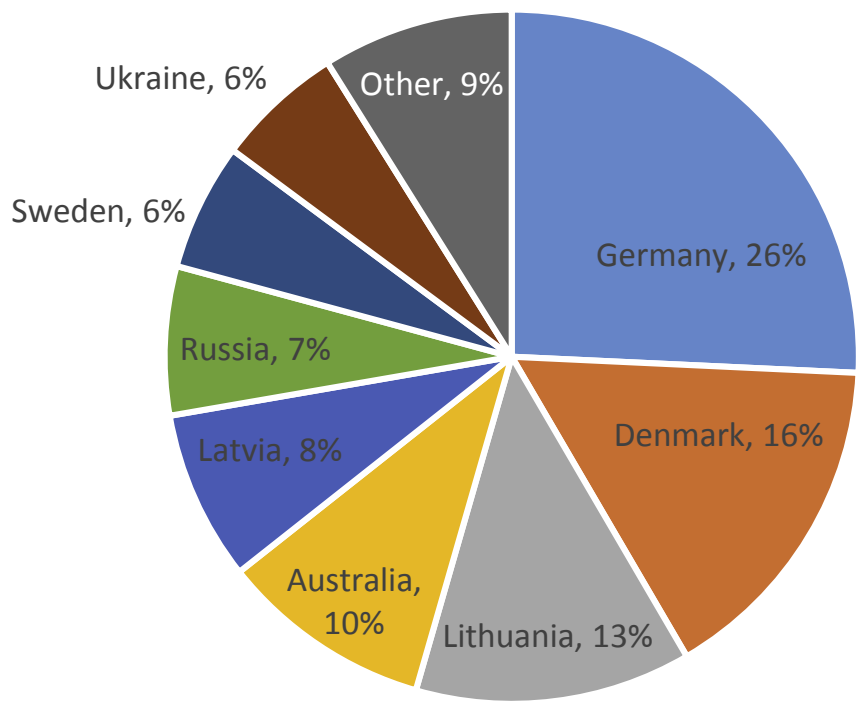

Fig. 2. Origin of FAME imports to Sweden, 2015 (data extracted from Swedish Energy Agency, 2016) (Note: Other includes (from higher to lowest share) UK, Romania, France, Poland, Belarus, Czech Republic, Hungary, Paraguay and Netherlands). countries have announced their plans to phase out coal plants by 2030. This would reduce the emissions of the electricity mix even further and enhance the benefits on emission reduction from transport electrification.

\subsubsection{Batteries' emissions}

The LCA on batteries modeled in SimaPro v8.4 refers to a Li-Ion rechargeable battery as listed in the Ecoinvent database v3.1 (Moreno Ruiz et al., 2014, 2013). The carbon emissions of this battery are calculated with the IPCC 2013 method and are estimated to be $6.19 \mathrm{~kg} \mathrm{CO}$ eq $/ \mathrm{kg}$ battery. The specific energy of the battery is assumed to be $80 \mathrm{Wh} / \mathrm{kg}$, in line with previous literature, such as Sinhuber et al. (2012) and Lindgren (2015). Other studies have assumed specific energy values of up to $100 \mathrm{Wh} / \mathrm{kg}$, as for example in Rogge et al. (2015). The specific energy strongly depends on battery chemistry and design and thus the values mentioned above are subject to a sensitivity analysis in Section 4.

The life cycle emissions from batteries have been modeled with an LCA perspective in various studies (Bi et al., 2015; Dunn et al., 2012; Ellingsen et al., 2014; Majeau-Bettez et al., 2011). Due to the various assumptions made in each study, there are uncertainties associated with the results obtained. Nevertheless, such results can serve as an indication and can be used for comparisons to the present analysis. A study recently published by (Romare and Dahllöf, 2017) includes a comprehensive literature review of available LCA studies for batteries used in electric vehicles. Based on this review, the authors conclude that greenhouse gas emissions of $150-200 \mathrm{~kg} \mathrm{CO} \mathrm{CO}_{2 \mathrm{eq}} / \mathrm{kWh}_{\text {battery }}$ correspond well to the current burden of battery production. Assuming the specific energy of the electric bus battery to be $80 \mathrm{Wh} / \mathrm{kg}$, as mentioned earlier, the value of $6.19 \mathrm{~kg} \mathrm{CO}$ 2eq $/ \mathrm{kg}$ battery corresponds to $77.37 \mathrm{~kg} \mathrm{CO}$ 2eq $/ \mathrm{kWh}_{\text {bat- }}$ tery which is approximately half of the median of the range indicated in Romare and Dahllöf (2017). To address such differences, the impact of both the estimated values for battery-associated emissions and the specific energy are considered in the sensitivity analysis in Section 4 of this paper.

The impacts from the battery use phase depend upon vehicle characteristics, drive cycles, and the electricity mix among others, and are excluded from this study. The battery emissions are calculated assuming an average battery lifetime of seven years, as shown in a recent study testing battery degradation in electric buses carried out in Denmark (Norregaard et al., 2016). The depreciation time for vehicles and infrastructure assumed in the model is 15 years. Thus, we take into account one battery replacement during the bus lifetime, with the impacts of this replacement included in the model estimations.

\subsection{Optimization model}

The model optimizes the distribution of charging infrastructure for battery electric buses (electric buses hereafter) in the city, taking into account current fuel alternatives. We combine geospatial analysis in the Geographic Information System (GIS) software ArcGIS, with input data managed with Python programming language, and cost and energy optimization performed in the General Algebraic Modeling System (GAMS). The model is applied to the bus network selected, i.e. the optimization occurs at the system's level and not for each bus route. We argue that there are significant benefits that can be accrued from synergies between the various bus routes. Therefore, an approach where each bus route is individually optimized was not preferred.

The structure of the model can be split in four main components: (i) the data processing component where information on the characteristics and costs of the bus and charging station 


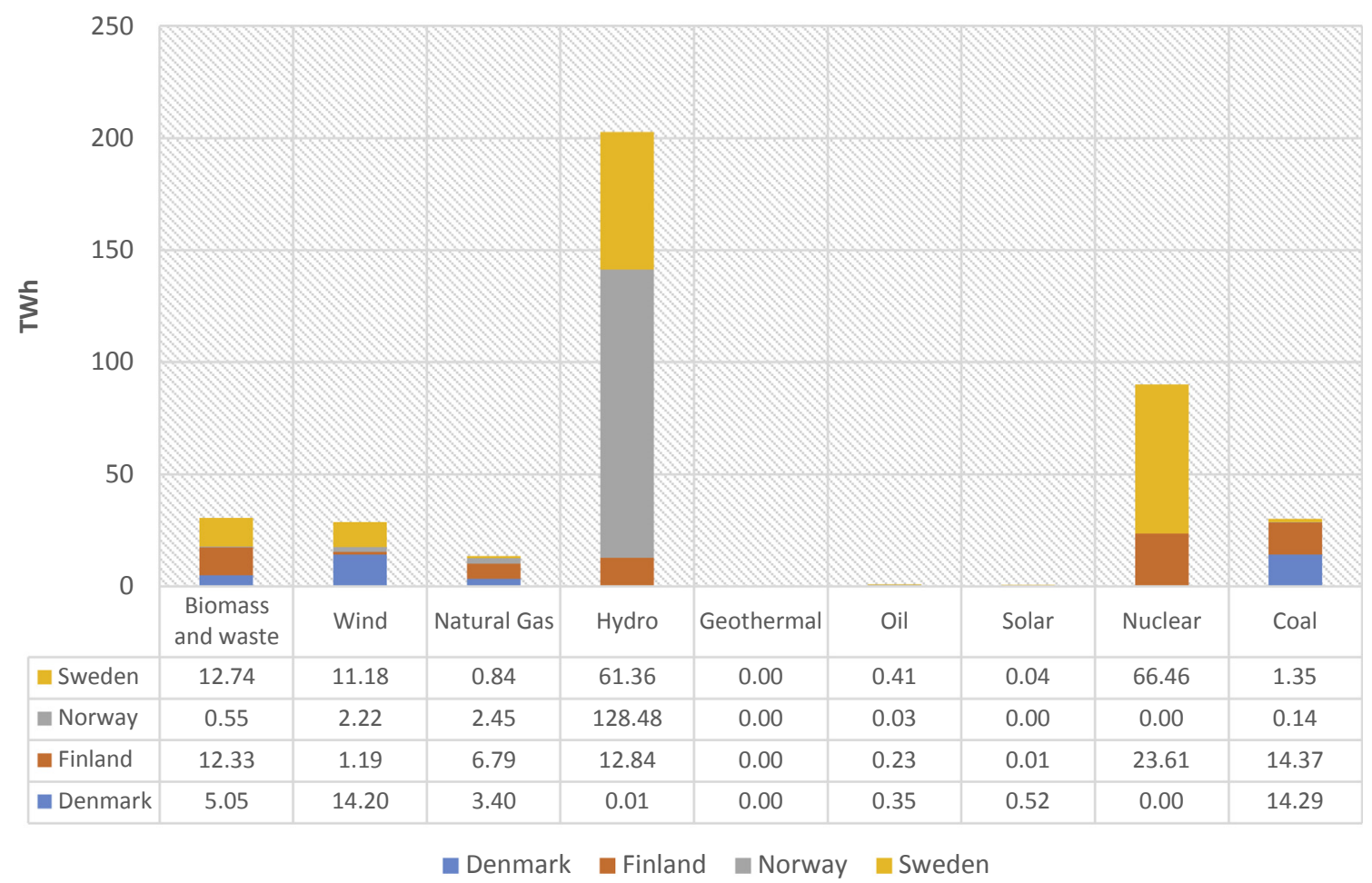

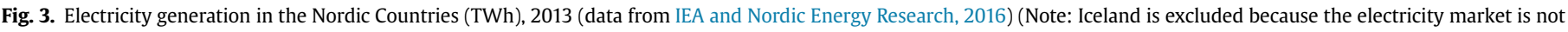
common as its grid is not connected to the other Nordic countries).

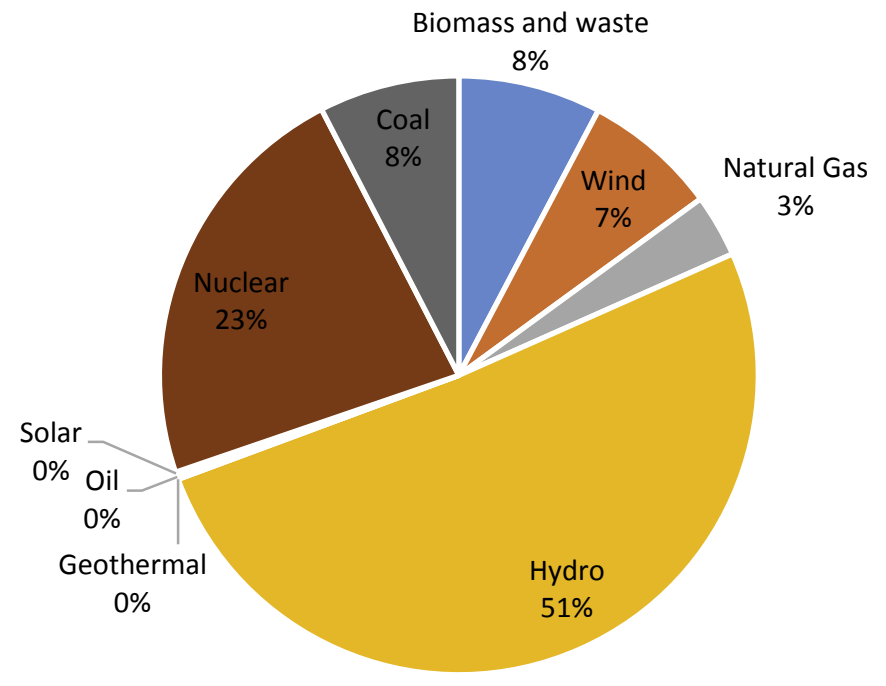

Fig. 4. Nordic electricity composition by primary energy source, 2013 (data from IEA and Nordic Energy Research, 2016) (Note: Iceland is excluded because the electricity market is not common as its grid is not connected to the other Nordic countries).

technologies as well as schedules is collected and managed; (ii) the geospatial component where bus routes are matched to their respective bus stops and the bus stop distance matrices are extracted; (iii) the optimization component, where the objective function is minimized; and (iv) the scenario analysis component, where the selected charging stations from the optimization component are located and sensitivity analysis on various parameters is performed.

The data collected fall within the following general categories: costs, technologies, and design-related parameters. When available, Swedish literature was prioritized for selecting the parameter values due to higher relevance to this case study. The infrastructure and vehicle costs are annualized, using a depreciation period of 15 years and discount rate of 5\% (SLL, 2015), which is in line with the assumptions made by the Stockholm Public Transport Authority for studies within the same context. It is assumed that no additional infrastructure costs occur for non-electric buses, since the infrastructure is already in place.

The optimization is performed in the model using the package for Mixed Integer Linear Programing (MILP) in the GAMS software using the solver CPLEX (McCarl et al., 2008). The model was initially developed in Xylia et al. (2017a). Here, an additional component focusing on emissions is developed. For more information on the optimization model the reader is referred to Xylia et al. (2017a) and Xylia et al. (2017b). The method for assessing the emissions is an addition to the previously developed model and described in more detail Section 3.3.

We apply energy balances for each station, with the necessary differentiation between start, end, and mid stops, i.e. different equations are applied when the stop is first or last in the route's distance matrix. The dependent variables are the binary variables $\mathrm{US}_{\mathrm{l}, \mathrm{s}, \mathrm{tech}}$, which indicates the need to install a charger at the stop or not, and $\mathrm{TUS}_{\mathrm{l}, \mathrm{s} \text {, tech }}$, which associates each bus route with a specific technology (biodiesel or electric). The positive variables of the model are $\mathrm{C}^{\text {total }}$ (the total annual costs), $\mathrm{E}^{\text {total }}$ (the total annual energy consumption), and $\mathrm{U}^{\text {total }}$ (the total annual emissions).

The objective function here is the total costs. The costs include infrastructure, operation and maintenance (O\&M), fuel, and vehicle costs for a selected bus network. Together with the costs, energy consumption and emissions (in $\mathrm{CO}_{2 e q}$ ) are calculated per bus route using the total number of trips in a year multiplied by the route length. 
The values and abbreviations of the parameters used in the equations are listed in Appendix Table A.1 and A.2.

The objective function for the total costs is the following:
The public transport schedule in Stockholm varies depending on the season. The schedule is different during the summer months (less trips and buses used). The schedule also varies between reg-

$C_{\text {total }}=\left\{\begin{array}{l}\sum_{l=1}^{L} \sum_{S=1}^{S} \sum_{\text {tech }=1}^{T E C H}\left(C_{l, \text { tech }}^{\text {infrastructure }} * U S_{l, s, \text { tech }}\right) \\ +\sum_{l=1}^{L} \sum_{\text {tech }=1}^{T E C H}\left[\left(C_{l, \text { tech }}^{O \& M}+C_{l, \text { tech }}^{\text {fuel }}\right) * L_{l} * T C_{l}+C_{l, \text { tech }}^{\text {vehicle }} * N_{l}^{\left.\text {vehicle } * T U S_{l, \text { tech }}\right]}\right.\end{array}\right.$

Equation 1: Estimating total costs of the bus network.

The total energy consumption is calculated as follows:

$E_{\text {total }}=\sum_{l=1}^{L} \sum_{\text {tech }=1}^{T E C H}$ Cons $_{\text {tech }} * L_{l} * T C_{l} * T U S_{l, \text { tech }}$

Equation 2: Estimating total energy consumption of the bus network.

\subsection{Assessment of $\mathrm{CO}_{2}$ emissions}

To answer the first and second research question (how largescale electrification affects the life cycle carbon emissions of the Stockholm bus network and how battery characteristics affect the environmental impact of electric buses), the total annual emissions of the bus network are obtained through estimating (i) the fuelassociated emissions, using the emission factors of various fuels presented in Section 3.1.1 (see Table 1); and (ii) the battery-associated emissions, taking into account the life cycle impact of battery production (see Section 3.1.2). Both components are based on the outputs of the LCA discussed in Section 3.1. With this structure, it is possible to get estimations on the total emissions, as well as the split between fuel and battery emissions. In line with the above, the total emissions of the selected bus network are calculated as follows: ular work days and weekends. We used therefore a day which was not during the summer schedule months and not during a weekend.

From the schedule, the unique trips can be extracted. When multiplied with each route's length, the total daily bus transport volume (in vehicle kilometers) is obtained. This can be multiplied with the energy consumption per vehicle-kilometer. Statistics published on the Swedish Public Transport Association's database show the average levels of pollutants from Stockholm's buses in 2016 (see Table 2). Assuming the energy consumption per vehiclekilometer for biodiesel buses, one can estimate the energy savings from electrification. Using the data on pollutants, the avoided exhaust emissions from bus electrification can be estimated. Following from that, the impacts of electrification in the inner city can be estimated.

\section{Results and discussion}

\subsection{Cost-optimization model results}

The locations considered for installing electric charging stations are: (i) at major public transport hubs; and (ii) at the start and end stops of bus routes. There are in total 480 public bus routes in Stockholm region. Out of them 143 (30\% of the total number of routes) pass the 10 largest public transport hubs where terminals for connecting to other public transport means (subway, commuter

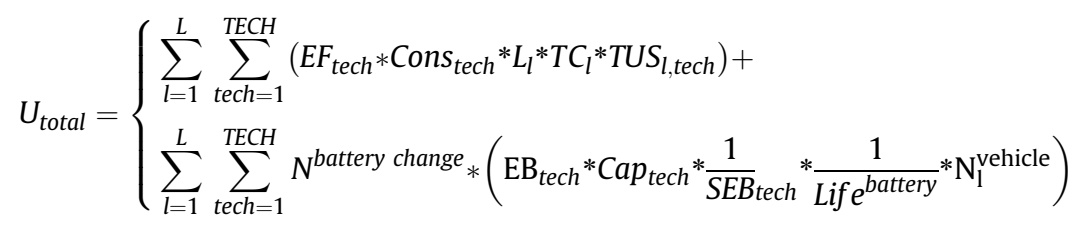

Equation 3: Calculation of total annual emissions in the optimization model (assuming one battery replacement during vehicle lifetime, $N_{\text {battery change }}=2$, Life battery $=7$ ).

We delimit our analysis to fuel and battery emissions, as discussed previously, under the assumption that these two components have the largest impact.

For answering the third research question (what impact bus electrification has on reduction of air pollutants $\left(P M, N O_{x}\right)$ in Stockholm's inner city), the number of daily trips per bus route based on the schedule data is estimated in the model. The number of daily trips for the inner city bus routes can be thus identified.

The day used for the analysis is a typical Monday in May 2016. train, light rail train) are in place. These 143 routes are the routes which are included in the optimization model.

Fig. 5 presents the cost-optimization results on the location of chargers, as well as the technology selected for each bus route

Table 2

Statistics on pollutants (in $\mathrm{g} / \mathrm{km}$ ) for Stockholm's bus fleet as of 2016 (Source: Svensk Kollektivtrafik, 2017).

\begin{tabular}{ll}
\hline Pollutant & average emissions for Stockholm bus fleet, 2016 $(\mathrm{g} / \mathrm{km})$ \\
\hline $\mathrm{NO}_{\mathrm{x}}$ & 3.64 \\
$\mathrm{PM}$ & 0.03 \\
$\mathrm{CO}_{\text {2eq }}$ & 315 \\
\hline
\end{tabular}




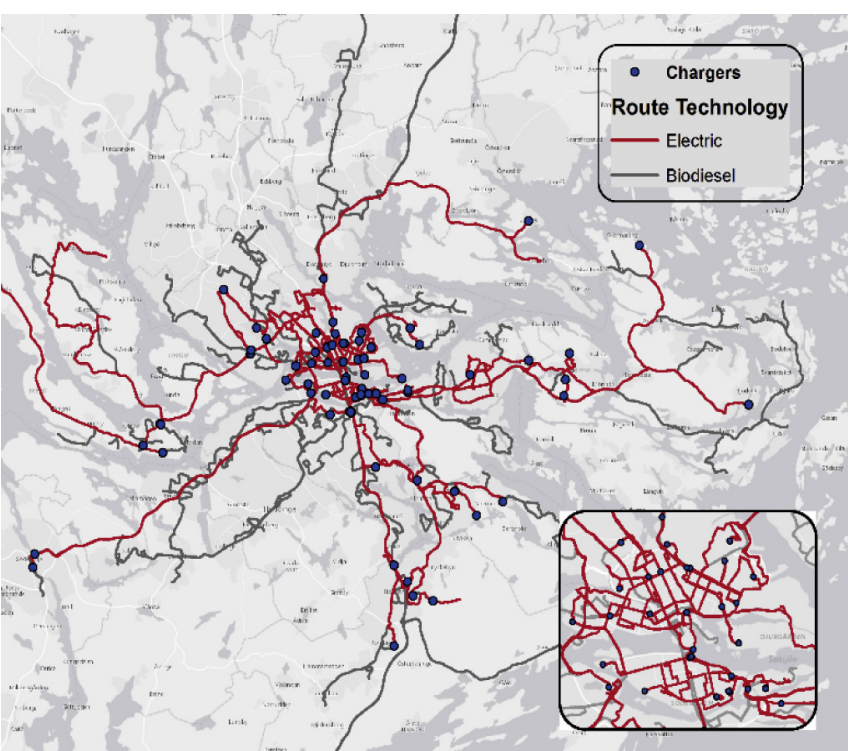

Fig. 5. Bus technology selection and electric bus charging station locations by the cost optimization model (battery capacity of $60 \mathrm{kWh}$ ). Map inset shows Stockholm's city in more detail.

represented in the model. The results shown here are for a battery capacity of $60 \mathrm{kWh}$ in the electric buses. The cost optimization results indicate that out of the 143 bus routes selected, 91 should operate on biodiesel (HVO) and the remaining 52 are operating on electricity.

Table 3 presents the results from the cost-optimization model for total annual costs, energy consumption, and emissions as well as a comparison with $100 \%$ electricity (certified and Nordic mix) and biodiesel (HVO and FAME). The total annual cost for running the system is 3.70 billion SEK. It should be noted that approximately $65 \%$ of the costs are related to operations and maintenance $(\mathrm{O} \& \mathrm{M})$. This is in line with previous studies for bus transport in Sweden (SKL, 2014; WSP, 2014a, 2014b), that indicate the high impact of O\&M costs on public transport costs. The total annual emissions of the selected bus network are estimated at $12.73 \mathrm{kt}$ $\mathrm{CO}_{2 \text { eq }} /$ year, with the fuel-associated emissions representing a share of $95 \%$ compared to the much smaller share of battery-associated emissions.

In Fig. 6, the total emissions of the bus network using different fuels are shown. This is to highlight the impacts of using specific fuels, and to provide a reference for comparison with the model results. In the latter, a combination of buses running on HVO and electricity is the cost-optimal solution. Using certified renewable electricity for the whole bus network results in the lowest emission impact. This is followed closely by the emissions estimated in the cost-optimization model (52 bus routes electrified, and the remaining routes on HVO, see Section 4.1). The emissions of the cost-optimized bus network are 50\% lower than emissions from a bus network running on $100 \%$ HVO. The emissions obtained for a system using $100 \%$ HVO are in the same range as a system operating on $100 \%$ Nordic electricity. The highest emissions are obtained from a $100 \%$ FAME system.

It can be noted that, although the Nordic electricity mix has a three times higher emission factor than HVO (see Table 1), it actually leads to total emissions which are comparable to HVO. The reason is that electric buses are more energy efficient and, as a result, the total energy consumption of the bus network is much lower ( $320 \mathrm{GWh}$ for electricity, $647 \mathrm{GWh}$ for HVO). It is also shown that, from an emissions reduction perspective, a full-electric bus fleet running on the average Nordic electricity mix is not better than a bus fleet running on HVO (see Fig. 6). The situation would be even less favorable for electricity mixes in other regions. For example, the EU electricity mix has an emission factor of 565 $\mathrm{gCO}_{2} \mathrm{eq} / \mathrm{kWh}$, which is about 4.5 times higher than the average Nordic mix emission factor (Covenant of Mayors Office and Joint Research Centre of the European Commission, 2014).

Additionally, there is a large difference between the emission impact of the Nordic electricity mix and the certified renewable electricity mix. This confirms that the origin of the electricity used for the buses is key for the reduction of emissions from the buses. Furthermore, it should be noted that the impact of second generation biofuels, such as HVO, is much lower than their first generation counterparts, such as FAME.

Finally, the results highlight that there is no completely emission-free solution when looking at the system from a life cycle perspective. In fact, even for the case of certified renewable electricity, there are emissions associated with the construction and operation of the power plants, wind farms etc., as well as the life cycle impacts of batteries and various components used. The difference in battery-associated emissions, more specifically, makes the electricity and HVO mix proposed for the operation of the bus network a compelling option when it comes to emissions reduction for public bus transport operation. The latter requires less investment on new infrastructure than a full electric bus network, but still leads to quite significant emission reductions.

Table 3

Annual costs, energy consumption and emission results from the cost-optimization model in comparison to various fuel alternatives.

\begin{tabular}{|c|c|c|c|c|c|}
\hline & $\begin{array}{l}\text { Cost-optimization results ( } 91 \text { routes with } \\
\text { HVO }+52 \text { routes with certified electricity) }\end{array}$ & $\begin{array}{l}\text { All routes with } \\
\text { certified electricity }\end{array}$ & $\begin{array}{l}\text { All routes with Nordic } \\
\text { electricity mix }\end{array}$ & $\begin{array}{l}\text { All routes with } \\
\text { biodiesel (HVO) }\end{array}$ & $\begin{array}{l}\text { All routes with } \\
\text { biodiesel (FAME) }\end{array}$ \\
\hline Costs (billion SEK ${ }^{\mathrm{a}} /$ year) & 3.67 & 3.91 & 3.91 & 3.86 & 3.86 \\
\hline Infrastructure (billion SEK/year) & 0.02 & 0.07 & 0.07 & 0 & 0 \\
\hline $\begin{array}{l}\text { Operation and Maintenance } \\
(O \& M) \text { (billion SEK/year) }\end{array}$ & 2.70 & 2.74 & 2.74 & 2.58 & 2.58 \\
\hline Vehicles (billion SEK/year) & 0.46 & 0.62 & 0.62 & 0.36 & 0.36 \\
\hline Fuel (billion SEK/year) & 0.49 & 0.48 & 0.48 & 0.92 & 0.92 \\
\hline $\begin{array}{l}\text { Energy consumption (GWh/ } \\
\text { year) }\end{array}$ & 393 & 320 & 320 & 647 & 647 \\
\hline Emissions (ktCO ${ }_{2 \mathrm{eq}} / \mathbf{y e a r}$ ) & 12.73 & 9.88 & 30.19 & 25.65 & 75.14 \\
\hline $\begin{array}{l}\text { Fuel-associated emissions } \\
\quad\left(\mathrm{ktCO}_{2} \text { eq/year }\right)\end{array}$ & 12.03 & 8.15 & 28.46 & 25.65 & 75.14 \\
\hline $\begin{array}{l}\text { Battery-associated emissions } \\
\quad\left(k t \mathrm{KO}_{2} \text { eq/year }\right)\end{array}$ & 0.70 & 1.73 & 1.73 & 0 & 0 \\
\hline
\end{tabular}

a SEK is the Swedish currency (Swedish Krona). The average exchange rate for 2017 is 1 SEK $=0.095 €$ (Oanda, 2018). 


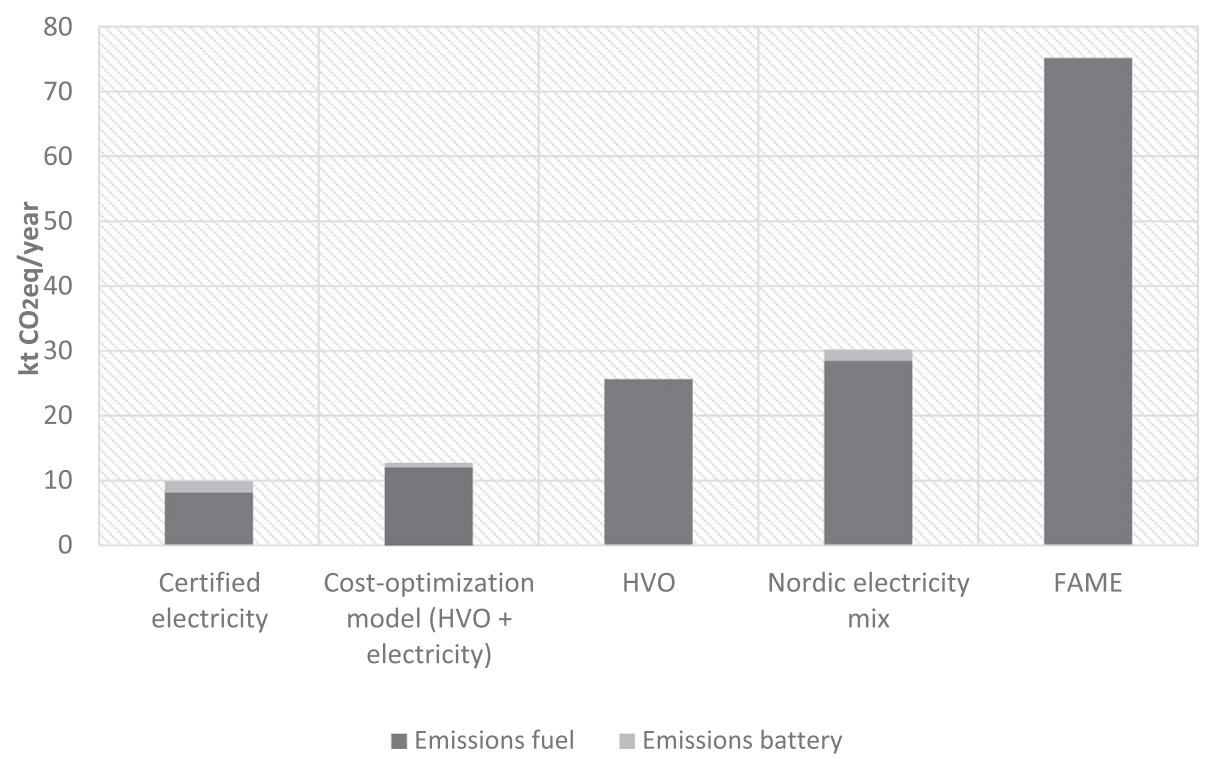

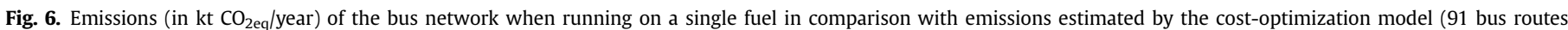
running on HVO and 52 bus routes running on certified electricity).

\subsection{Sensitivity analysis considering battery characteristics}

A sensitivity analysis has been carried out for the batteryassociated emissions, which were earlier presented in Table 3. This is done by changing the specific battery emission parameter. The sensitivity range is from $-20 \%$ to $180 \%$ of the parameter's original value ( $6190 \mathrm{gCO}_{2 \mathrm{eq}} / \mathrm{kg}$ battery, see Section 2$)$. This range is in line with the specific battery emission values estimated in previous literature (see Section 3.1.2). Fig. 7 shows the linear impact of battery emissions on the overall emissions of the selected bus network when this parameter changes. The change starts at $1 \%$ of the total emissions for the lower margin and reaches $9 \%$ of the total emissions for the higher margin. This confirms what was mentioned in Section 4.1, i.e. that the majority of emissions of the bus network originates from fuel-related emissions, and not from battery-related emissions.

There are 143 bus routes considered in the model, and it is assumed that 10 buses operate each route. From the investigated bus routes, 52 are electrified in the cost optimization model, thus 520 buses are electric. With the assumed battery capacity of $60 \mathrm{kWh}$, energy density of $80 \mathrm{Wh} / \mathrm{kg}$, and one battery change per bus, the total battery weight that is taken into account in the sensitivity analysis is 390 tons.

The next sensitivity analysis applied to the model focuses on varying battery sizes, i.e., the battery capacity. A range between a minimum of $10 \mathrm{kWh}$ and a maximum of $300 \mathrm{kWh}$ is considered in order to illustrate the differences in the electrification potential of the bus routes, and the emissions associated to each system configuration. It should be noted that a battery with $300 \mathrm{kWh}$ capacity only requires charging at the depot. In that case, opportunity charging is not needed along the route.

Fig. 8 shows the result of the sensitivity analysis when varying the battery capacity. The share of battery emissions varies from $0.25 \%$ with a battery capacity of $10 \mathrm{kWh}$ to $30 \%$ with a battery capacity of $300 \mathrm{kWh}$. When the battery capacity increases, the emissions associated with the fuel consumption decrease, due to the electrification of a higher number of bus routes. This is due to the fact that with higher battery capacities longer routes could be electrified. On the other hand, the impact on emissions from the batteries also increases and, with a larger number of electric buses, more batteries are used. In addition, batteries with higher capacity are larger and heavier, which is also associated with higher life

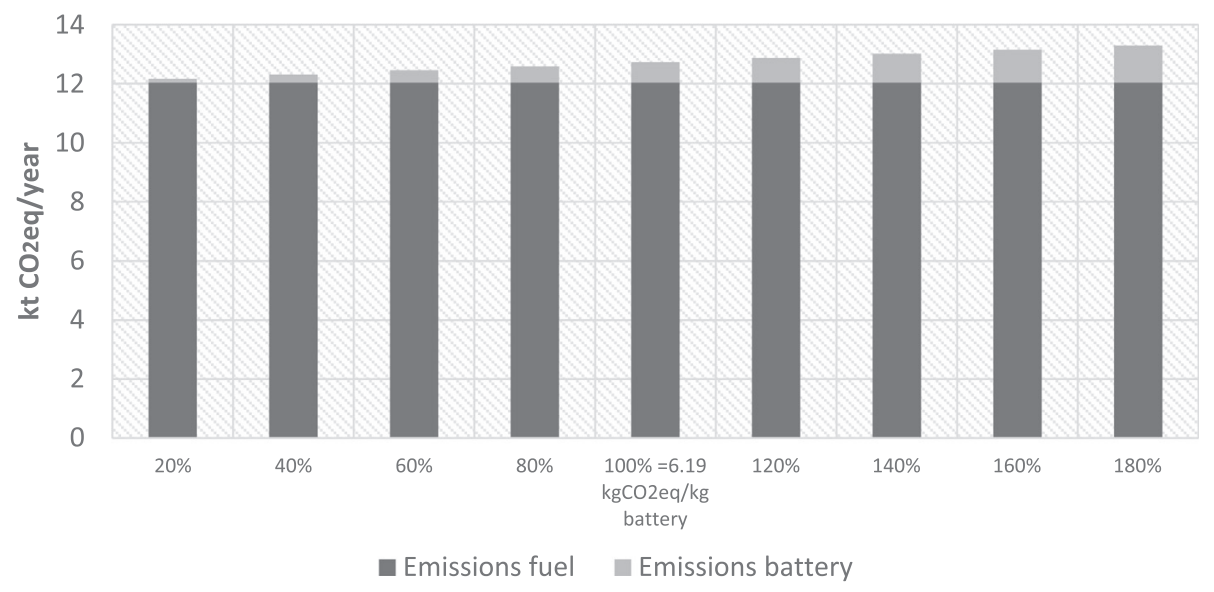

Fig. 7. Sensitivity analysis on the total emissions (in $\mathrm{ktCO}_{2 \mathrm{eq}} / \mathrm{year}$ ) estimated in the optimization model for varying specific battery emissions (in gCO ${ }_{2} \mathrm{eq} / \mathrm{kg}$ battery). 


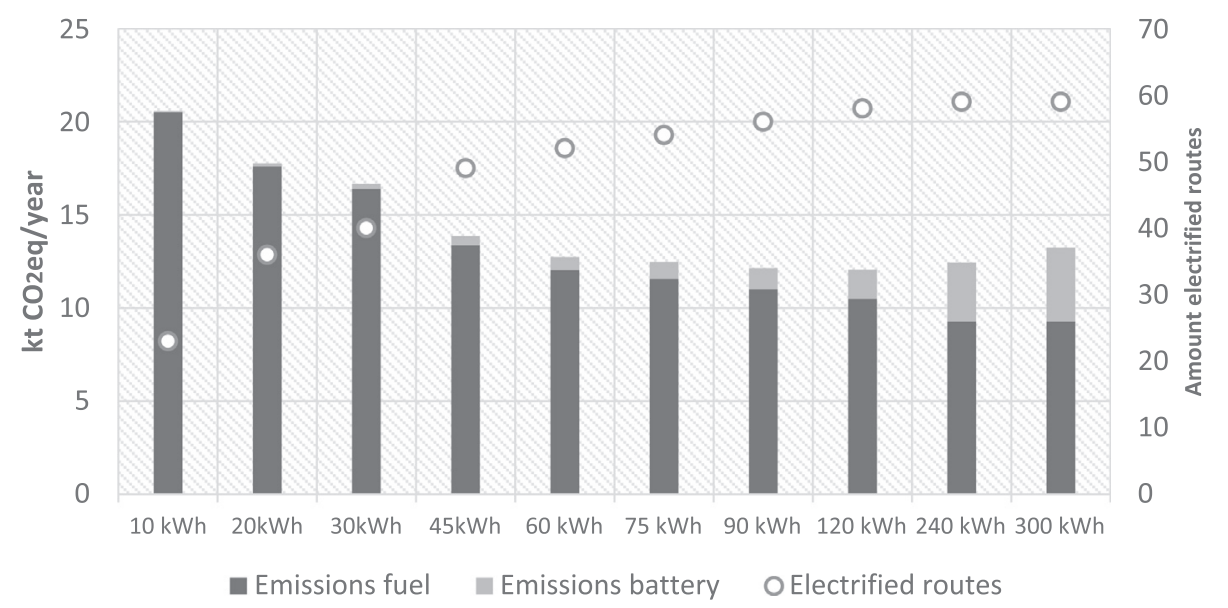

Fig. 8. Sensitivity analysis of total emissions in relation to battery capacity.

cycle carbon emissions.

Thus, from the emissions perspective, a larger battery (i.e. with capacity of $300 \mathrm{kWh}$ ) is not advantageous, regardless of the fact that higher electrification rates can be more easily achieved. The most positive results in terms of emissions reductions of the bus network selected are obtained with a battery capacity of $120 \mathrm{kWh}$. In this case, the increase of battery emissions is compensated by the decrease in emissions due to the use of renewable electricity.

It should be pointed out that this estimation does not take into account the fact that the larger the battery is, the more it weighs. This added weight could affect the energy consumption of the bus negatively, as well as reduce passenger carrying capacities. Methodologies for evaluating the impact of such effects on greenhouse gas emissions of electric and electric hybrid vehicles have been developed in detail in Meinrenken and Lackner (2015).

In our case, we use a simpler approach that fits well with the structure of the optimization model to estimate the variations in energy consumption depending on the battery weight. The proposed value in Sinhuber et al. (2012) for estimation of traction energy consumption in relation to the battery of the bus is equal to $0.072 \mathrm{kWh} / \mathrm{km}^{*} t$, where $t$ is the total weight of the bus in tons. The curb weight of the bus is assumed to be 12.5 tons in the case of a 12$\mathrm{m}$ bus in line with Göhlich et al. (2014). From the above the traction-related energy consumption is calculated and the auxiliaries' energy consumption is then added in order to obtain the total energy consumption per kilometer. The difference in the consumption for a 10 and $300 \mathrm{kWh}$ battery is $29 \%$.

Fig. 9 shows the effect of battery weight-related energy consumption on the results of the sensitivity analysis for varying capacities. The difference in fuel-associated emissions shown in Figs. 8 and 9 are small for battery capacities below $60 \mathrm{kWh}$. This can be explained by the fact that smaller shares of the bus network are electrified, thus having lower impact on emission reduction compared to bus routes running on biodiesel. This is not the case for battery capacities higher than $60 \mathrm{kWh}$, when more bus routes become electric and the batteries become heavier. For a battery capacity of $300 \mathrm{kWh}$, there is a $15 \%$ difference in fuel-associated emissions due to the higher energy consumption resulting from the heavier batteries. The point where the emissions are lowest is still somewhere between 90 and $120 \mathrm{kWh}$ though.

Another aspect that should be discussed is that for the case of fast charging, power optimized batteries are used, while for the case of depot charging (slow charging) energy optimized batteries are preferred. The power optimized batteries have lower energy density but can withstand higher charging power, and they also have a longer life than energy optimized batteries. For example, in Lajunen (2018) the power optimized batteries have double cycle life than energy optimized batteries. On the other hand, energy optimized batteries have higher energy density and therefore can store more energy per $\mathrm{kg}$ of their mass.

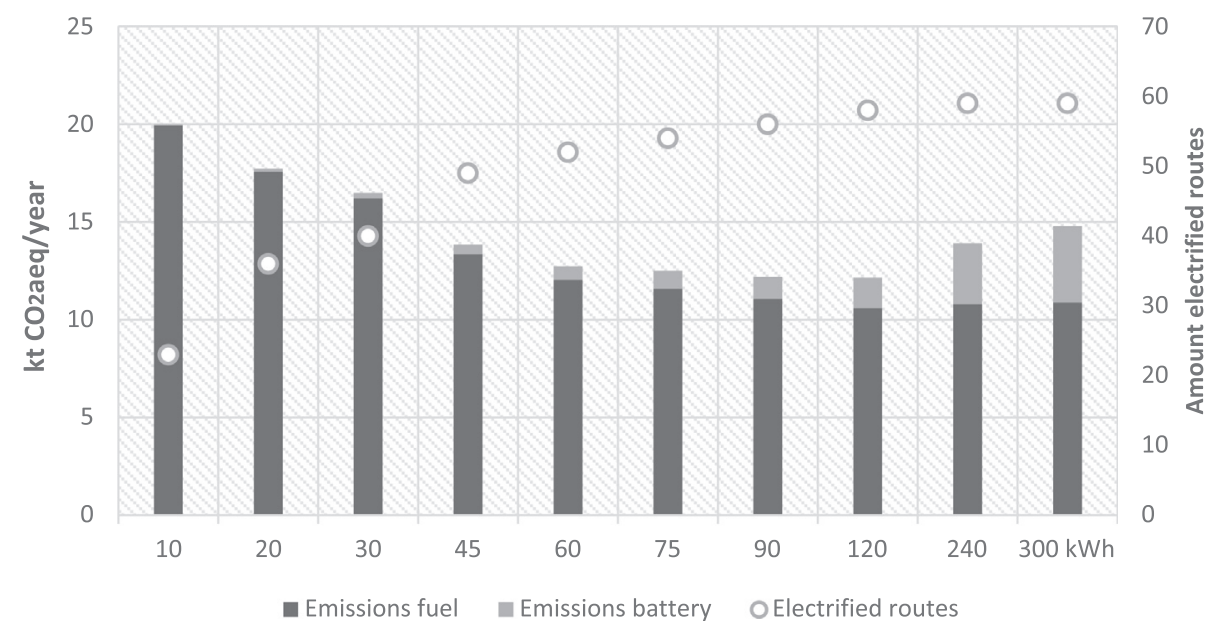

Fig. 9. Sensitivity analysis of total emissions in relation to battery capacity, adjusting the energy consumption to the weight of the battery. 
The effects on battery life from the various charging strategies (fast vs. slow charging) are not captured in detail in this model. Although power optimized batteries are costlier than energy optimized batteries (a difference of $40 \%$ in costs per $\mathrm{kWh}$, see Lajunen (2018)), still their smaller size (in terms of capacity in kWh) and longer cycle life compared to the energy optimized batteries could lead to a similar range of total battery costs, even if more replacements would be needed for batteries withstanding fast charging.

It should be noted that higher energy densities (both for power and energy optimized batteries) could help to reduce the emissions associated with batteries, and support the electrification of a larger part of the bus network, as they would entail more energy per kg of battery. Fig. 10 shows the results of the sensitivity analysis for different values of the battery's specific energy. It can be observed that the share of battery emissions decreases as the specific energy increases, while the share of emissions from fuels remains stable. This result is expected and shows that the better the energy density of the battery, the lower its impact will be on the emissions. On the other hand, a battery of higher energy density will cost more. The results are in line with findings of LCA studies in the literature, such as in Held and Schücking (2017), where a positive overall impact GWP from electric vehicles is estimated based on empirical data from battery electric vehicles. However, the potential negative effects of battery usage on some of the LCA impact categories, such as the acidification potential, are highlighted.

\subsection{Inner city electrification and air quality}

There are differences between the local and global impacts of transport emissions. Fuel emissions refer to local emissions, while battery-associated emissions occur at the global level, during production stages. A detailed LCA can give the global environmental impact of each option, which has to be considered also in relation to the local impacts.

Road transport electrification could have significant impact on air quality improvement in dense urban environments. Electric vehicles have no exhaust gases and, therefore, could help to reduce local air pollution. This is a universal problem and, even if Stockholm enjoys good air quality in general, there are particular bottlenecks where congestion leads to air pollution, especially in the inner city. The limits for the harmful Nitrogen Oxide $\left(\mathrm{NO}_{\mathrm{x}}\right)$ levels have been surpassed multiple times in the year 2016 in air quality measurement stations located in busy streets of Stockholm's inner city, such as Hornsgatan, Sveavägen, and Norrlandsgatan
(Hurkmans et al., 2017). Similar observations can be made for $\mathrm{PM}_{10}$ limits (SLB analys, 2016). Electric buses can be part of the solution against air pollution in Stockholm's inner city.

Most of the bus stops selected by the model for installing charging infrastructure are located in the inner city. This is not surprising as this is where the higher concentration of major public transport hubs are, and thus also the location of potential charging stations. From a total of 480 bus routes operating in the Stockholm region, 161 routes cross the inner city, and 21 routes are completely within the inner city limits. From these 21 routes, the model identifies 10 that could be electrified. The electrified routes and charging locations are shown in Fig. 11. The analysis in this section refers to these routes.

From the schedule, the unique trips can be extracted. When multiplied with each route's length, the total daily bus transport volume (in vehicle kilometers) is obtained. The transport volume for the 10 inner city routes that are electrified is 44846 vehicle-km/ day. If the electric bus energy consumption is assumed to be, on average, $1.5 \mathrm{kWh} / \mathrm{vehicle-km}$ and the biodiesel (HVO) bus consumption is $4.5 \mathrm{kWh} /$ vehicle- $\mathrm{km}$, the electrification of these routes leads to energy savings equivalent to approximately $44 \mathrm{GWh}$ /year. These savings represent $6.4 \%$ of the current total energy

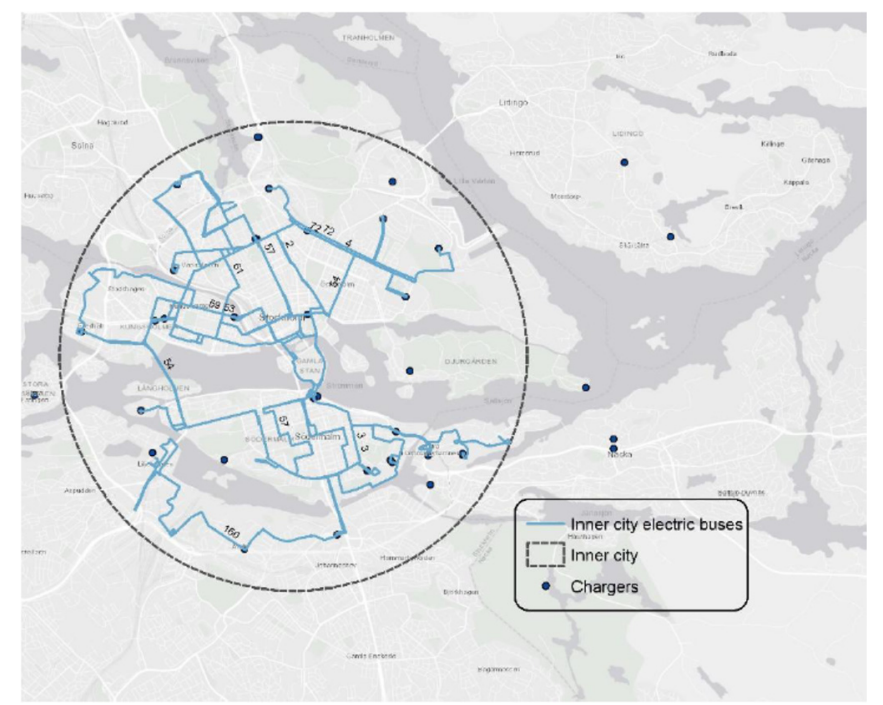

Fig. 11. Bus electrification in Stockholm's inner city - electrified bus routes and location of chargers.

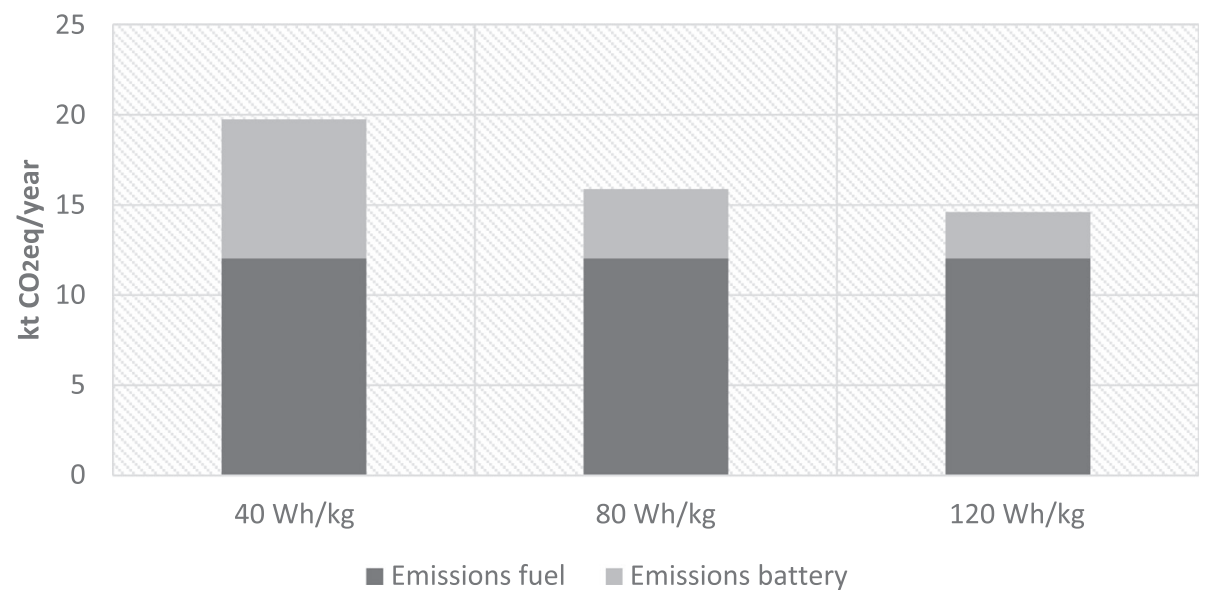

Fig. 10. Sensitivity analysis on total emissions in relation to the energy density of the battery. 
consumption of Stockholm's bus fleet (690 GWh/year according to Svensk Kollektivtrafik, 2017). Statistics published on the Swedish Public Transport Association's database show the average levels of pollutants from Stockholm's buses in 2016 (see Table 2).

The above mentioned energy savings and transport volume lead to avoided exhaust emissions. Table 4 summarizes the amount of avoided pollutants, when taking into amount the total annual transport volume of the selected inner city routes. Previous reports show that the total amount of $\mathrm{NO}_{\mathrm{x}}$ from road transport for the whole of Stockholm city was $3100 \mathrm{tNO}_{\mathrm{x}} /$ year, while $\mathrm{PM}_{10}$ was 860 $\mathrm{tPM}_{10}$ /year (Länsstyrelsen i Stockholms Län, 2012). Assuming that this is the current range of annual $\mathrm{NO}_{\mathrm{x}}$ and $\mathrm{PM}_{10}$ emissions from road transport in Stockholm, removing the emissions from buses would lead to approximately $2 \%$ reduction in $\mathrm{NO}_{\mathrm{x}}$ emissions and 0.05\% reduction in $\mathrm{PM}_{10}$ emissions from road transport in Stockholm, as listed in Table 4. The limited potential impact obtained for local pollution is not surprising as transport volume and pollution related to private and goods transport is much larger than for bus transport. On the other hand, when specific corridors in the inner city are assessed, these reductions can be significant, as the share of public transport volume there is larger.

It should be noted that tailpipe emissions can be greatly affected by local conditions, such as elevation, road traffic, and the specific fuel blends used. The values reported for Stockholm are much lower than other studies observed in literature, such as Cooper et al. (2014) were $\mathrm{NO}_{\mathrm{x}}$ and $\mathrm{PM}_{10}$ estimations for buses using NExBTL fuel (a market name for HVO from the company Nesté) show approximately doubled values compared to Stockholm. More specifically, the $\mathrm{NO}_{\mathrm{x}}$ emissions were around $7 \mathrm{~g} / \mathrm{km}$ and the PM were around $0.08 \mathrm{~g} / \mathrm{km}$ in this meta-analysis (Cooper et al., 2014). In Stockholm, there is a significant amount (approximately 30\% of the fleet) of non-diesel engine buses that have lower $\mathrm{NO}_{\mathrm{x}}$ and $\mathrm{PM}_{10}$ emissions than their diesel counterparts. More specifically, in 2016, out of the 2149 buses comprising the public transport fleet, 324 were gas engine buses and 369 were ethanol buses (Svensk Kollektivtrafik, 2017b).

\section{Conclusions}

This paper evaluates the impact of large-scale electrification on life cycle emissions of the Stockholm bus network. An optimization model is applied for the bus network of the city of Stockholm. In an earlier study by Xylia et al. (2017a), the model focused on total operation cost and energy consumption. Here, the focus is on emissions from the various fuels used, as well as the batteries needed for the electric buses. These two aspects are assumed to have the largest impact among other system components and are thus investigated in detail. The battery emissions, battery capacity, and specific energy were subjected to sensitivity analysis.

Higher battery capacities could support the electrification of larger parts of the bus network and therefore reduce emissions associated with fuel consumption. However, the analysis indicates that this does not necessarily lead to lower emissions in total. This is due to the fact that batteries of higher capacity are larger and heavier, and lead to higher carbon emissions. Moreover, the results

\section{Table 4}

Avoided NOx, $\mathrm{PM}$ and $\mathrm{CO}_{2}$ emissions for proposed electrification of inner city routes (calculations based on Table 2 and estimated annual transport volume of inner city routes).

\begin{tabular}{ll}
\hline Pollutant & avoided pollution from inner city electrification (t/year) \\
\hline $\mathrm{NO}_{\mathrm{x}}$ & 60 \\
$\mathrm{PM}_{10}$ & 0.49 \\
$\mathrm{CO}_{2 \text { eq }}$ & 5160 \\
\hline
\end{tabular}

of this analysis show that heavier batteries could not only lead to higher battery-related emissions, but also to higher fuel-associated emissions, as the energy consumption increases. The results show that a battery capacity of $120 \mathrm{kWh}$ has a better life cycle impact than, for example, a 60 or $300 \mathrm{kWh}$ battery.

Moreover, the life cycle emission impact from batteries decreases at higher energy density values. This indicates that batteries with denser specific energy are preferable from an emissions point of view. It is expected that technology improvements in batteries shall lead to reduced environmental impact, as well as an improved ratio for the battery weight and its capacity. This would result in less overall energy consumption and emissions from electric buses.

The results highlight the impact of fuel choices on the environmental impact of a bus network operation. The use of renewable electricity of lower life cycle emissions is a better choice than first generation biofuels, for example. The use of first generation biofuels should additionally be discussed in the context of the "food vs. fuel" debate (see, for example, Silveira and Johnson (2016)). However, the use of second generation biofuels, such as HVO, can directly compete with electricity mixes of low environmental impact, such as the Nordic electricity mix. Therefore, it is necessary to choose electricity from renewable sources in order to obtain the full benefits from electrification. The certified renewable electricity for the Swedish case has an emission factor which is $90 \%$ lower than the emission factor of the average Nordic electricity mix.

According to the model results, a $100 \%$ electrified bus network would not be the cost-optimal solution. The implementation of such a solution would require high investment costs on infrastructure which could not be balanced by the reduced fuel costs. We propose a solution where electricity and biodiesel routes coexist, with higher rates of electrification in the city centre, where most of the benefits of improved local air quality due to electric buses could be accrued. The results show that the impact on emissions from this combined solution is actually quite close to the impact of a fully electrified bus network, and this is also due to the fact that battery-related emissions are lower under this configuration.

Electrification can help to reduce local air pollution caused by buses in the inner city, such as $\mathrm{NO}_{\mathrm{x}}$ and PM. However, the analysis indicates that the overall impact of such reduction would be small compared to the local pollution caused by private transport. Thus, electrification of bus fleets should be implemented in combination with strategies for increased use of public transport, in order to maximize road transport emission reduction in urban environments.

Future research should focus on lifecycle impacts of batteries and charging stations (for both fast and slow charging) required for electrification which could be subject to sensitivity analysis under various lifecycle lengths. Additionally, exploring the differences in terms of lifecycle impacts from various battery types and chemistries would be beneficial in understanding the implications of battery-related choices for electrification of road transport.

\section{Acknowledgements}

A short version of the paper was presented at ICEEE2017/ ISEV2017, July 26-29, Sweden. This paper is a substantial extension of the short version of the conference paper. The first author's research was financed by the Swedish Energy Agency under the project "Wireless Bus Stop Charging"(project number: 39254-1), a collaboration between KTH, Scania, the Stockholm City Council (SLL), the municipality of Södertälje and Vattenfall. IIASA's Tropical Futures Initiative (TFI) and the EC project BECOOL (grant number: 744821) are gratefully acknowledged for their support. The 
Swedish Energy Agency, the Transport Administration of the Stockholm City Council (SLL) and Vattenfall are gratefully acknowledged for the data and insights provided. Finally, we thank the two anonymous reviewers for their valuable comments that helped improve the paper.

\section{Abbreviations}

EU

FAME

GA

GAMS
HVO Hydrotreated Vegetable Oil

LCA Life Cycle Analysis

NOx Nitrogen Oxide

PM Particle Matter

SEK Swedish Crown

VOC Volatile Organic Compounds

WTW Well-to-Wheel

\section{Appendix}

Parameter values used in the model.

\begin{tabular}{|c|c|c|}
\hline Parameter & Value & Source \\
\hline \multicolumn{3}{|l|}{ Energy consumption bus ( $\mathbf{k W h} / \mathbf{k m})$} \\
\hline Biodiesel bus & 4.50 & adjusted from Mahmoud et al. (2016) \\
\hline Biogas bus & 6 & adjusted from Hagberg et al. (2016) \\
\hline Electric bus & 1.50 & adjusted from Hagberg et al. (2016); Lindgren, 2015; \\
\hline \multicolumn{3}{|l|}{ Maximum battery capacity (kWh) } \\
\hline Electric bus & 60 & Lajunen and Lipman, 2016 \\
\hline \multicolumn{3}{|c|}{ Minimum state-of-charge (SOC) for the battery (\%) } \\
\hline \multicolumn{3}{|l|}{ Power capacity charging station $(\mathbf{k W})$} \\
\hline Electric-Conductive & 300 & Bombardier, 2016; Siemens, 2016 \\
\hline Electric-Inductive & 200 & \\
\hline \multicolumn{3}{|l|}{ Infrastructure costs $\left(\mathrm{SEK}^{1}\right)$} \\
\hline \multicolumn{3}{|l|}{ Charging station costs (SEK) } \\
\hline Electric-Conductive & $1,500,000$ & Lindgren, 2015 \\
\hline Electric-Inductive & $2,000,000$ & \\
\hline \multicolumn{3}{|l|}{ Pickup for charging station (SEK) } \\
\hline Electric-Conductive & 0 & Lindgren, 2015 \\
\hline \multicolumn{3}{|l|}{ Battery (SEK/Wh) } \\
\hline Electric-Conductive & 10 & Lindgren, 2015 \\
\hline \multicolumn{3}{|l|}{ Fixed installation costs (SEK) } \\
\hline Grid connection & 175,000 & Lindgren, 2015 \\
\hline Grid connection annual fee & 40,000 & \\
\hline Building costs and permits & 400,000 & authors' assumption \\
\hline \multicolumn{3}{|l|}{ Vehicle costs (SEK) } \\
\hline Biodiesel bus & $2,500,000$ & Lajunen and Lipman, 2016 \\
\hline Biogas bus & $3,000,000$ & SLL, 2015 \\
\hline Electric bus & $4,500,000$ & \\
\hline \multicolumn{3}{|c|}{ Operation \& Maintenance $(O \& M)$ costs $(S E K / \mathbf{k m})$} \\
\hline \multicolumn{3}{|c|}{ Driver cost } \\
\hline Salary costs, insurance etc. & 16.40 & Hagberg et al., 2016 \\
\hline \multicolumn{3}{|l|}{ Maintenance } \\
\hline Biodiesel bus & 1.50 & Lajunen and Lipman, 2016 \\
\hline Biogas bus & 3 & Hagberg et al., 2016; SLL, 2015 \\
\hline Electric bus & 3 & \\
\hline Biogas bus & 7.10 & \\
\hline Electric bus & 1.40 & \\
\hline
\end{tabular}

${ }^{1}$ SEK is the Swedish currency (Swedish Krona). The average exchange rate for 2016 is 1 SEK $=0.095 €$ (Oanda, 2018).

Table A.2

Indices, variables, and parameters used in the optimization model.

\begin{tabular}{ll}
\hline Indices & bus route \\
$\mathrm{L}$ & bus stop \\
$\mathrm{S}$ & bus technology (biodiesel, biogas, or electricity) \\
tech & \\
Binary Variables & binary variable indicating if charging station is installed at bus stop $\{0,1\}$ \\
$\mathrm{US}_{\mathrm{l}, \mathrm{s}, \mathrm{tech}}$ & binary variable associating bus routes with specific technology $\{0,1\}$ \\
$\mathrm{TUS}_{\mathrm{l}, \text { tech }}$ & \\
Positive Variables & total costs \\
$\mathrm{C}^{\text {total }}$ &
\end{tabular}


Table A.2 (continued)

\begin{tabular}{|c|c|}
\hline$E^{\text {total }}$ & total energy consumption \\
\hline $\mathrm{U}^{\text {total }}$ & total emissions \\
\hline \multicolumn{2}{|l|}{ Parameters } \\
\hline $\mathrm{C}_{\mathrm{l}, \mathrm{tech}}^{\mathrm{O} \& \mathrm{M}}$ & operation \& maintenance costs of the technology (tech) that belongs to bus line (l) \\
\hline$C_{l, \text { tech }}^{\text {fuel }}$ & annual fuel costs of the technology (tech) that belongs to bus line (1) \\
\hline$C_{l, t e c h}^{\text {infrastructure }}$ & annualized costs for infrastructure of the technology (tech) that belongs to bus line ( 1 ) \\
\hline$C_{l, \text { tech }}^{\text {vehicle }}$ & annualized costs for vehicles of the technology (tech) that belongs to bus line (l) \\
\hline Cap tech $_{1}$ & maximum power stored in the bus using the technology (tech) \\
\hline Cons $_{\text {tech }}$ & power consumption per bus using the technology (tech) \\
\hline $\mathrm{EB}_{\text {tech }}$ & emission factor for battery based on technology (tech) \\
\hline $\mathrm{EF}_{\text {tech }}$ & emission factor per fuel for each technology (tech) \\
\hline $\mathrm{L}$ & number of bus routes \\
\hline$\tilde{\mathrm{L}}$ & set of all bus routes \\
\hline Life battery $^{\text {bat }}$ & battery lifetime \\
\hline $\mathrm{L}_{\mathrm{l}}$ & length of the bus route \\
\hline $\mathrm{N}_{\mathrm{l}}^{\text {vehicle }}$ & number of vehicles deployed for operating each route (1) \\
\hline$N^{\text {battery change }}$ & number of battery replacements assumed for bus lifetime \\
\hline $\mathrm{SEB}_{\text {tech }}$ & Specific energy of the battery \\
\hline $\mathrm{TC}_{\mathrm{l}}$ & total annual number of trips for the bus route (1) \\
\hline TECH & number of technologies \\
\hline
\end{tabular}

\section{References}

Abdul-Manan, A.F.N., 2015. Uncertainty and differences in GHG emissions between electric and conventional gasoline vehicles with implications for transport policy making. Energy Pol. 87, 1-7. https://doi.org/10.1016/j.enpol.2015.08.029.

Bi, Z., Song, L., De Kleine, R., Mi, C.C., Keoleian, G.A., 2015. Plug-in vs. wireless charging: life cycle energy and greenhouse gas emissions for an electric bus system. Appl. Energy 146, 11-19. https://doi.org/10.1016/j.apenergy.2015.02. 031.

Bombardier, 2016. Primove e-bus [WWW Document] accessed 9.18.16. http:// primove.bombardier.com/fileadmin/primove/content/GENERAL/ PUBLICATIONS/English/PT_PRIMOVE_Datasheet_2015_Braunschweig_EN print 110dpi.pdf.

Chan, S., Miranda-Moreno, L.F., Alam, A., Hatzopoulou, M., 2013. Assessing the impact of bus technology on greenhouse gas emissions along a major corridor: a lifecycle analysis. Transport. Res. Part D Transport Environ. 20, 7-11. https:// doi.org/10.1016/j.trd.2013.01.004.

Cooper, E., Arioli, M., Carrigan, A., Lindau, L.A., 2014. Exhaust emissions of transit buses: Brazil and India case studies. Res. Transport. Econ. 48, 323-329. https:// doi.org/10.1016/j.retrec.2014.09.059.

Covenant of Mayors Office, Joint Research Centre of the European Commission, 2014. Reporting Guidelines on Sustainable Energy Action Plan and Monitoring.

Creutzig, F., Jochem, P., Edelenbosch, O.Y., Mattauch, L., Vuuren, D.P. van, McCollum, D., Minx, J., 2015. Transport: a roadblock to climate change mitigation? Science 350, 911-912. https://doi.org/10.1126/science.aac8033.

Dreier, D., Silveira, S., Khatiwada, D., Fonseca, K.V.O., Nieweglowski, R., Schepanski, R., 2018. Well-to-Wheel analysis of fossil energy use and greenhouse gas emissions for conventional, hybrid-electric and plug-in hybridelectric city buses in the BRT system in Curitiba, Brazil. Transport. Res. Part D Transport Environ. 58, 122-138. https://doi.org/10.1016/j.trd.2017.10.015.

Dunn, J.B., Gaines, L., Sullivan, J., Wang, M.Q., 2012. Impact of recycling on cradle-togate energy consumption and greenhouse gas emissions of automotive lithiumion batteries. Environ. Sci. Technol. 46, 12704-12710. https://doi.org/10.1021/ es302420z.

Durango-Cohen, P.L., McKenzie, E.C., 2017. Trading off costs, environmental impact, and levels of service in the optimal design of transit bus fleets. Transp. Res. Procedia 23, 1020-1032. https://doi.org/10.1016/j.trpro.2017.05.056.

Ellingsen, L.A.W., Majeau-Bettez, G., Singh, B., Srivastava, A.K., Val??en, L.O., Str?? mman, A.H., 2014. Life cycle assessment of a lithium-ion battery vehicle pack. J. Ind. Ecol. 18, 113-124. https://doi.org/10.1111/jiec.12072.

Ensslen, A., Schücking, M., Jochem, P., Steffens, H., Fichtner, W., Wollersheim, O., Stella, K., 2017. Empirical carbon dioxide emissions of electric vehicles in a French-German commuter fleet test. J. Clean. Prod. 142, 263-278. https://doi. org/10.1016/j.jclepro.2016.06.087.

European Commission, 2016. Paris Agreement [WWW Document] accessed 9.19.16. http://ec.europa.eu/clima/policies/international/negotiations/paris/index_en. htm.

European Parliament, 2009. Directive 2009/28/EC of the European Parliament and of the Council of 23 April 2009. Off. J. Eur. Union 140, 16-62. https://doi.org/10. 3000/17252555.L_2009.140.eng.

García Sánchez, JA, López Martínez, JM, Lumbreras Martín, J. Flores Holgado, M.N., Aguilar Morales, H., 2013. Impact of Spanish electricity mix, over the period 2008-2030, on the life cycle energy consumption and GHG emissions of electric, hybrid diesel-electric, fuel cell hybrid and diesel bus of the Madrid transportation system. Energy Convers. Manag. 74, 332-343. https:// doi.org/10.1016/j.enconman.2013.05.023.
Göhlich, D., Kunith, A., Ly, T., 2014. Technology assessment of an electric urban bus system for berlin. WIT Trans. Built Environ. 138, 137-149. https://doi.org/10. 2495/UT140121.

Hagberg, M., Roth, A., Bäckström, S., 2016. Analys Av Biogas till El För Bussdrift Och Biogas Som Bränsle till Bussdrift I Stadstrafik 23. https://doi.org/Report C 171.

He, X., Zhang, S., Ke, W., Zheng, Y., Zhou, B., Liang, X., Wu, Y., 2018. Energy consumption and well-to-wheels air pollutant emissions of battery electric buses under complex operating conditions and implications on fleet electrification. J. Clean. Prod. 171, 714-722. https://doi.org/10.1016/j.jclepro.2017.10.017.

Held, M., Schücking, M., 2017. Life cycle assessment of electric vehicles in shuttle traffic - field test results of the project RheinMobil. In: Proc. 30th Int. Electr. Veh. Symp. Exhib. EVS30, pp. 1-11.

Hurkmans, J., Johansson, C., Forsberg, B., 2017. Fossilfri Fordonsflotta I Stockholm Betydelse För Luftkvalitet Och Hälsa.

IEA, 2016. Energy Technology Perspectives 2016 - towards Sustainable Urban Energy Systems. Intenrational Energy Agency, Paris.

IEA, 2015. CO2 Emissions from Fuel Combustion 2015, CO2 Emissions from Fuel Combustion. OECD Publishing, Paris. https://doi.org/10.1787/co2 fuel-2015-en.

IEA, Nordic Energy Research, 2016. Nordic Energy Technology Perspectives.

IPCC, 2007. IPCC Fifth Assessment Report. The Physical Science Basis.

ISO, 2006. ISO 14040: Environmental Management - Life Cycle Assessment Principles and Framework.

Jochem, P., Babrowski, S., Fichtner, W., 2015. Assessing CO 2 emissions of electric vehicles in Germany in 2030. Transport. Res. Part A Policy Pract 78, 68-83. https://doi.org/10.1016/j.tra.2015.05.007.

Jolliet, O., Saade-Sbeih, M., Shaked, S., Jolliet, A., Crettaz, P., 2016. Environmental Life Cycle Assessment. CRC Press, Boca Raton.

Kunith, A., Mendelevitch, R., Goehlich, D., 2016. Electrification of a City Bus Network: an Optimization Model for Cost-effective Placing of Charging Infrastructure and Battery Sizing of Fast Charging Electric Bus Systems (No. 1577). Berlin.

Lajunen, A., Lipman, T., 2016. Lifecycle cost assessment and carbon dioxide emissions of diesel, natural gas, hybrid electric, fuel cell hybrid and electric transit buses. Energy 106, 329-342. https://doi.org/10.1016/j.energy.2016.03.075.

Lajunen, A., 2018. Lifecycle costs and charging requirements of electric buses with different charging methods. J. Clean. Prod 172, 56-67.

Länsstyrelsen i Stockholms Län, 2012. Åtgärdsprogram För Kvävedioxid Och Partiklar ( Pm10 ) I Stockholms Län. Länsstyrelsen i Stockholms Län, Stockholm.

Lindgren, L., 2015. Full Electrification of Lund City Bus Traffic a Simulation Study. Lund University, Lund.

Mahmoud, M., Garnett, R., Ferguson, M., Kanaroglou, P., 2016. Electric buses: a review of alternative powertrains. Renew. Sustain. Energy Rev. 62, 673-684. https://doi.org/10.1016/j.rser.2016.05.019.

Majeau-Bettez, G., Hawkins, T.R., StrØmman, A.H., 2011. Life cycle environmental assessment of lithium-ion and nickel metal hydride batteries for plug-in hybrid and battery electric vehicles. Environ. Sci. Technol. 45, 4548-4554. https://doi org/10.1021/es103607c.

McCarl, B., Meeraus, A., Eijk, P., Bussieck, M., Dirkse, S., Steacy, P., 2008. Expanded Gams User Guide Version 22.9.

McKenzie, E.C., Durango-Cohen, P.L., 2012. Environmental life-cycle assessment of transit buses with alternative fuel technology. Transport. Res. Part D Transport Environ. 17, 39-47. https://doi.org/10.1016/j.trd.2011.09.008.

Meinrenken, C.J., Lackner, K.S., 2015. Fleet view of electrified transportation reveals smaller potential to reduce GHG emissions. Appl. Energy 138, 393-403. https:// doi.org/10.1016/j.apenergy.2014.10.082.

Moreno Ruiz, E., Lévová, T., Bourgault, G., Wernet, G., 2014. Documentation of 
Changes Implemented in Ecoinvent Data 3.1. Ecoinvent, Zurich.

Moreno Ruiz, E., Weidema, B.P., Bauer, C., Nemecek, T., Vadenbo, C.O., Treyer, K. Wernet, G., 2013. Documentation of Changes Implemented in Ecoinvent Data 3.0. Ecoinvent Report, St. Gallen.

Norregaard, K., Johnsen, B., Hedegaard Gravesen, C., 2016. Battery Degradation in Electric Buses. Aarhus.

Oanda, 2018. Historical Exchange Rates [WWW Document].

Pré, 2016. SimaPro Database. Manual Methods Library.

Regeringskansliet, 2013. Fossilfrihet På Väg: Utredningen Om Fossilfri Fordonstrafik SOU 2013:84. Fritzes Offentliga Publikationer, Stockholm.

Rogge, M., Wollny, S., Sauer, D.U., 2015. Fast Charging Battery Buses for the Electrification of Urban Public Transport-a Feasibility Study Focusing on Charging Infrastructure and Energy Storage Requirements 4587-4606. https://doi.org/10. 3390/en8054587.

Romare, M., Dahllöf, L., 2017. The Life Cycle Energy Consumption and Greenhouse Gas Emissions from Lithium-ion Batteries and Batteries for Light-duty Vehicles.

Siemens, 2016. Siemens EBus Charging [WWW Document] accessed 9.18.16. http:// w3.siemens.com/topics/global/de/elektromobilitaet/PublishingImages/ ladetechnik-busse/pdf/ebus-brochure-en.pdf.

Silveira, S., Johnson, F.X., 2016. Navigating the transition to sustainable bioenergy in Sweden and Brazil: lessons learned in a European and International context. Energy Res. Soc. Sci. https://doi.org/10.1016/j.erss.2015.12.021.

Sinhuber, P., Rohlfs, W., Sauer, D.U., 2012. Study on power and energy demand for sizing the energy storage systems for electrified local public transport buses. In: 2012 IEEE Veh. Power Propuls. Conf. https://doi.org/10.1109/VPPC.2012 6422680
SKL, 2014. Vad Förklarar Kollektiv- Trafikens Snabba Kostnadsökning ? Sveriges Kommuner och Landsting Stockholm.

SLB analys, 2016. Luften I Stockholm: Årsrapport. Stockholms Stad, Stockholm.

SLL, 2015. Information Om Genomförd Behovsanalys Av Övergång till Eldriven Busstrafik. Stockholm Läns Landsting, Stockholm.

Song, Q., Wang, Z., Wu, Y., Li, J., Yu, D., Duan, H., Yuan, W., 2017. Could urban electric public bus really reduce the GHG emissions: a case study in Macau? J. Clean. Prod. 1-10. https://doi.org/10.1016/j.jclepro.2017.11.206.

Svensk Kollektivtrafik, 2017a. Miljö- Och Fordonsdatabasen Frida.

Svensk Kollektivtrafik, 2017b. Miljö- Och Fordonsdatabasen Frida.

Swedish Energy Agency, 2016. Drivmedel Och Biobränslen 2015. Eskilstuna.

Vattenfall, 2017. Elens Ursprung Och Miljöpåverkan [WWW Document] accessed 5.25.17. https://www.vattenfall.se/elavtal/energikallor/elens-ursprung/.

WSP, 2014a. Konsekvenser Över Elbussar I Stocholm- Kalkyl Över Elbussar Stockholm. Stockholm.

WSP, 2014b. Särkravens Betydelse För Busstrafikens Kostnader. WSP Analys \& Strategi Stockholm, Stockholm.

Xylia, M., Leduc, S., Patrizio, P., Kraxner, F., Silveira, S., 2017a. Locating charging infrastructure for electric buses in Stockholm. Transport. Res. Part C Emerg. Technol. 78, 183-200. https://doi.org/10.1016/j.trc.2017.03.005.

Xylia, M., Leduc, S., Patrizio, P., Silveira, S., Kraxner, F., 2017b. Developing a dynamic optimization model for electric bus charging infrastructure. Transp. Res. Procedia 27, 776-783. https://doi.org/10.1016/j.trpro.2017.12.075.

Xylia, M., Silveira, S., 2017. On the road to fossil-free public transport: the case of Swedish bus fleets. Energy Pol. 100, 397-412. https://doi.org/10.1016/j.enpol. 2016.02.024. 